\title{
Yod
}

Revue des études hébraïques et juives

19 | 2014

Aharon Appelfeld, cinquante ans d'écriture

\section{From Excess to Origin: Traversing Time Zones as an Act of Redemption in The Man who Never Stopped Sleeping by Aharon Appelfeld}

Traverser le temps pour atteindre la rédemption: Le garçon qui voulait dormir d'Aharon Appelfeld

משארית לראשית: חציית איזורי זמן כפעולה של גאולה ב"האיש שלא פסק לישון"לאהרון אפלפלד לרית: משית

\section{Rina Dudai}

\section{(2) OpenEdition}

Electronic version

URL: https://journals.openedition.org/yod/2177

DOI: $10.4000 /$ yod. 2177

ISSN: 2261-0200

\section{Publisher}

INALCO

\section{Printed version}

Date of publication: 30 May 2014

ISBN: 978-2-85831-214-6

ISSN: 0338-9316

\section{Electronic reference}

Rina Dudai, "From Excess to Origin: Traversing Time Zones as an Act of Redemption in The Man who Never Stopped Sleeping by Aharon Appelfeld", Yod [Online], 19 | 2014, Online since 16 April 2014, connection on 08 July 2021. URL: http://journals.openedition.org/yod/2177 ; DOI: https://doi.org/ $10.4000 /$ yod. 2177

This text was automatically generated on 8 July 2021.

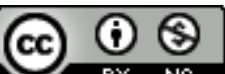

Yod est mis à disposition selon les termes de la Licence Creative Commons Attribution - Pas d'Utilisation Commerciale 4.0 International. 


\title{
From Excess to Origin: Traversing Time Zones as an Act of Redemption in The Man who Never Stopped Sleeping by Aharon Appelfeld
}

\author{
Traverser le temps pour atteindre la rédemption: Le garçon qui voulait \\ dormir d'Aharon Appelfeld
}

משארית לראשית: חציית איזורי זמן כפעולה של גאולה ב"האיש שלא פסק

לישון"לאהרון אפלפלד

\section{Rina Dudai}

1 In this paper, I would like to draw a link between trauma, religiosity and the art of writing by means of a journey towards the origin. The path of this journey attempts to circumvent the traumatic experience by reaching a point in time and space before the traumatic event, from which a new world can be created. Access to this point of origin is impossible without a passage through the transcendent by means of a religious mental state that elevates the traumatized subject beyond the helpless position of the broken self. The fictional world of poetic writing is the site where this transcendent journey in time is made possible.

2 I will elucidate this claim through an analysis of the novel The Man Who Never Stopped Sleeping by Aharon Appelfeld.

The novel describes the journey of an adolescent that begins in Europe at the end of the Second World War and culminates in Eretz-Yisrael just before the outbreak of the War of Independence. At the beginning of the journey, the hero Irwin, nicknamed "the sleeping boy" by the other exiles, is submersed in an ongoing state of slumber that is periodically interrupted by gradually growing intervals of wakefulness. Throughout the first part of his journey he is asleep, carried to the Italian coast by the other Holocaust refugees with whom he travels. From there he migrates to Eretz-Yisrael. When he arrives, Irwin joins the Hagana youth regiments and is immediately sent off to battle, 
where he is wounded in both legs and subsequently hospitalized. At the hospital and sanatorium he undergoes a long process of therapy and recovery during which he experiences another, inner journey in search of his own personal identity, finally discovering his destiny as a writer. The novel ends as Irwin, the hero, completes the first chapter of his novel, titled "The First Home", in which he tries, as he says, "to drink water from the well of life". The Man Who Never Stopped Sleeping thus also relates the initial stages of the act of writing itself, and sets up a novel within a novel.

Before reaching this final version, the hero writes several drafts for the chapter. In this paper I would like to follow these attempts up to the crystallization of the final text. I will show how these drafts set up a fundamental paradigm for a narrative of circumventing a state of traumatic distress; a narrative that proceeds through a religious experience towards the sanctification of the hero as a poetic writer.

In his essay "A preacher without a pulpit, a believer without a church", ${ }^{1}$ literary critic Yigal Schwartz challenges the critical discourse of Appelfeld's work which suffers, in his opinion, from a "blind spot" due to an "obsessive adherence" (as he calls it) to the "trauma-sublimation model": a model in which the repetition of a traumatic experience via poetic representation establishes a sense of control. Schwartz proposes an alternative critical model, the "seance model", which he believes is especially pertinent to Appelfeld's late work. According to Schwartz, in his late works Appelfeld inserts "ghost voices" into his literary apparatus that enable him to access the world of the dead. Schwartz interprets these voices as a shift away from personal, mental, and psychological issues towards an affinity with the collective national viewpoint.

6 I would like to suggest that the trauma model is crucial to the underlying experience that constitutes Appelfeld's personal, national, and poetic identity, and it nourishes the entire web of his literary works throughout his literary biography, including his later work. Criticism is indeed required to pay attention to shifts in the model when necessary, but for an understanding of Appelfeld's works, I believe the trauma model should remain fundamental. Trauma is defined as an event that generates an exceptionally negative emotional experience that the subject has no way of weaving into the story of his/her life. ${ }^{2}$ Trauma is considered to be an illness of time: it destroys the continuity of time and eradicates the distinctions between present and past, between the self and the other, between the body and the world, and between interior and exterior. Poetic writing has the power to reorganize internal reality and extricate the subject from the chaotic state of the traumatized self, at the brink of its disintegration. By constructing the stages of redemption from trauma through poetic writing as set up in Appelfeld's novel, I would like to establish a framework for discussion in which concepts from the realm of trauma explain the religious experience of communion with the world of the dead as part of the redemptive process, rather than as a shift away from personal issues and towards a tribal affinity. I claim that the adherence to a transcendental mental position, based on a mystical-religious experience following extreme trauma, is a stage on the way to the reconstitution of the self, as well as the poetic self.

7 In Writing History, Writing Trauma ${ }^{3}$ LaCapra discusses the concept of excess in the context of extreme traumatic events. LaCapra claims that at the heart of the traumatic experience lies excess, evading representation and making-present the trauma through an inability to articulate it. ${ }^{4}$ This "excess" that refuses to reveal itself is expressed in the novel The Man Who Never Stopped Sleeping through the liminal site of slumber. I will 
proceed to present the almost imperceptible metamorphoses undergone by the hero in this liminal site of sleep.

The novel begins with a description of the deep slumber into which Irwin has fallen:

Since the end of the war I've been in a state of continual slumber. True, I move from train to train, from truck to truck, and sometimes from carriage to carriage, but always through a thick and dreamless sleep [...] the things that happened to me during those days of slumber, I will probably never know [...]

When he is sleeping, the hero is submersed in an inaccessible realm of deep amnesia. This place of slumber is the liminal site at which the traumatic experience is registered but not appropriated, processed, or represented in consciousness and language. This is the "excess," which can only be experienced, not known; to use the terms of Kathy Caruth, this is the latency period.

Sleep in the novel serves as a kind of placenta, a protective membrane that envelops the narrator until he reenters the world. He describes the moment of awakening in terms of a birth: "now I feel that I've been emitted from a protected place to the blinding light that wounds me" (p.14). The involuntary expulsion from a protected space inevitably rips apart the protective membrane. This process is described as a double existence: the hero is awake, but nevertheless continues to be nurtured by the darkness of slumber. The experience of being wounded in battle and the subsequent hospitalization create a new reality that transforms the nature of Irwin's sleep. During this kind of sleep he starts dreaming and furthermore, even begins to daydream. Irwin sees the faces of people more clearly than ever before, as they are "etched out of the darkness and their inner life shines on their faces" (p. 129).

11 During the gradual recovery process, slumber is accompanied by a significant process of preparation for writing "The First Home", a gradual awakening that is reflected in the three versions Irwin writes before the final text. These versions are especially interesting because they signify the crystallization of the various stages in the process through which the traumatic experience is refined into the written text. The three drafts that appear in the text are in fact early texts written by Appelfeld himself, which were published in Israeli periodicals in the early stages of Appelfeld's poetic biography. Two of the three attempts (the first and the third attempt) are poems. Appelfeld, indeed, began his literary career as a poet. ${ }^{5}$ During the years 1952-1959, he published dozens of poems in various literary periodicals and newspapers, and in Appelfeld's own biography, poetry-writing precedes the writing of prose. The second attempt that appears in the novel is the opening chapter of the short story "Slowly" that appeared in the short story collection Smoke, Appelfeld's first book published by Achshav publishing house in 1962.

12 The novel The Man Who Never Stopped Sleeping thus explicitly identifies its hero with the author by inserting the lyrical poems and the prose section originally written by Appelfeld into the hero's text. Through this superposition, Appelfeld blurs the boundary between the author's writing and his hero's, as the hero returns to the author's literary biography and repeats his primal act of creation. Tracing the use he makes of his early texts within another work brings to light the mental process undergone by the writer that leads him from the trauma, through the experience of revelation, and ultimately to the redemptive act of writing.

13 The first draft written by Irwin includes a four-line poem. The poem's first line signifies the heart of the trauma, the lack, the lacuna; the unspoken, unrepresented excess that 
remains locked within the pain and sealed with words welded in the furnace of suffering.

That night, I wrote four lines:

And not a word was left

That wasn't melded in the furnace of pain

The volcano within closed up

Barred behind locked doors.

I corrected and corrected again and I knew there was more to correct, but my

hands were fists, and I laid my pen down on the paper (p. 175). 
This journey to the origin is in fact a driving force in Appelfeld's work. The journey he undertakes traverses the boundaries of his own biological life, as well as his poetic biography.

In the novel The Man Who Never Stopped Sleeping, the narrator undergoes a long journey towards his "first home", a journey that begins in a deep slumber of forgetting, continues through a double-life of wakefulness alongside sleep, and ends with autobiographical writing that sets up a narrative of retrospective redemption-not towards the afterlife, but in reverse, towards the origin. The "self" that has been unraveled by trauma is reconstituted by means of the existence that preceded the traumatic experience, from within the abysmal existence of an origin that enables the poetic act of creation. The novel ends with the words of the frightened mother, warning him against the hazards of the journey: "'You shouldn't go out on your own, these are cold and dangerous regions [...] let the faraway places come to you', she said, and disappeared from my view" (p. 236).

Appelfeld is not Lot's wife who turns back to look towards Sodom, and he does not write of a Sodomic experience. His writing goes further. The author of Gilgamesh had no name. He was called: "the man who gazed into the abyss". In his work, Appelfeld is the man who gazes into the abysmal origin, and from it he excavates a story of the construction of a new and purified continuum, thus redeeming the disintegrated self.

\section{NOTES}

1. Yigal Schwartz (2011). "A Preacher without a Pulpit, a Believer without a Church: In the Footsteps of the Novel Wild Blossoming by Aharon Appelfeld". From Twenty-four Readings of the Works of Aharon Appelfeld. Ed. by Avidov Lipsker and Avi Sagi. Bar Ilan Publishing House and Hartman Institute: Ramat Gan [Hebrew].

2. J. Laplanche \& J.B. Pontalis (1973). The Language of Psychoanalysis. Trans. by D.N. Smith. W.W. Norton \& Company: New York.

3. Dominick LaCapra (2001). Writing History, Writing Trauma. John Hopkins University Press.

4. Amos Goldberg (2006). "Introduction" for Writing History, Writing Trauma [Hebrew]. Trans. by Yaniv Farkash. Riesling, Yad Vashem Publishing House: Tel Aviv.

5. Yigal Schwartz (2009). A Believer without a Church [Hebrew]. Dvir: Tel Aviv.

6. Ibid. p. 197. Due to lack of time, I am unable to discuss the interaction set up between the context of the original text and the context of the inserted text; I will just mention that the mental difficulties that come up in the original context are deeply anchored in trauma, while the difficulties raised here have been transferred to the struggles of writing. 


\section{ABSTRACTS}

In this paper I will address an aspect of the literary work of Aaron Appelfeld, that binds the traumatic experience of the Holocaust with a religious state of mind and with poetic writing. I will illustrate my position by referring to Appelfeld's book The Man who never stopped sleeping. I will link religiosity to a strategy of circumventing traumatic memory. In my view, Appelfeld's coping with the traumatic memory involves substitution of the void of the trauma with adherence to religiosity, which is identified with an ecstatic act of poetic writing. For Appelfeld, as expressed for example in his First Person Essays (1979), religiosity represents the experience, emotion and personal attitude to the transcendental, which is also intimately related to creative writing. In his view, the unspoken residue of the trauma points toward the beginning of his own life and also that of his ancestors. The trajectory of the route which Appelfeld follows in reconnecting to life takes him backwards to the primordial sources of his family. This is a morbid act with an Orphic dimension, yet for Appelfeld is a source of life. In his return home, to the "beginnings", his parents and grandparents and grand-grandparents, Appelfeled seemingly returns to the pre-traumatic time, mending the shattered fragments via his writing while attempting to heal his threatened Self.

Je voudrais aborder dans cet article un aspect de l'œuvre littéraire d'Aharon Appelfeld qui met en relation l'expérience traumatique de la Shoah avec un sentiment religieux et avec l'écriture poétique. J'illustrerai mon propos en faisant référence au livre d'Appelfeld Le garçon qui voulait dormir. Il me semble que la religiosité pourrait être vue comme une stratégie de contournement de la mémoire traumatique. De mon point de vue, la confrontation d'Appelfeld avec la mémoire traumatique implique la substitution du vide engendré par le trauma avec un attachement à la religiosité, vue comme un acte extatique d'écriture poétique. Pour Appelfeld, la religiosité représente l'expérience, l'émotion et l'attitude personnelle par rapport à la transcendance, une expérience qui est très proche de l'acte créateur de l'écriture. Dans cette perspective, le résidu inexprimé du trauma renvoie au début de sa propre vie et de celle de ses ancêtres. La trajectoire qui le remet en contact avec la vie le conduit aussi vers les origines primordiales de sa famille. Il s'agit d'un acte morbide, à la dimension orphique, mais pour Appelfeld c'est une source de vie. En revenant chez lui, aux origines, à ses parents, ses grands-parents et ses arrière-grands-parents, Appelfeld semble retourner au temps d'avant le trauma, en réparant ainsi les brisures de sa vie par l'écriture et en essayant de guérir son être meurtri.

במאמר זה אציג היבט מסוים ביצירתו של אפלפלד הקושר בין טראומת השואה, החוויה הרלגיוזית

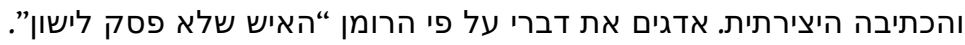


INDEX

Subjects: littérature

אפלפלד, שואה, טראומה, רליגיוזיות, גאולה, האיש שלא פסק לישוןמילות מפתח:

Mots-clés: religiosité, sources primordiales, rédemption, Le garçon qui voulait dormir, Appelfeld Aharon (1932-)

Keywords: Holocaust, trauma, excess, religiosity, primordial sources, redemption, The Man Who Never Stopped Sleeping, Appelfeld Aharon (1932-), literature

Chronological index: Shoah 